\title{
Listening Across Difference: Oral History as Learning Landscape
}

\author{
Steven High
}

\begin{abstract}
Oral history as a field of research, teaching, archival collection, community building or engagement, truth and reconciliation, and creative practice, emerged with the diffusion of the tape recorder in the 1960s and 1970s. This was a time of enormous social and political upheaval. As a result, oral history was quickly taken up by feminists, working-class and queer activists, racial minorities, and other marginalized people who sought to record the hidden stories that would otherwise be lost. This article introduces readers to the field of oral history, its methodology and ethics. Oral history is a creative practice, open to adaptation and experimentation. As it is a place of listening across difference, oral history interviewing presents itself as a unique learning landscape. Several pedagogical examples are also shared.
\end{abstract}

\section{Background}

People have always shared stories. Stories tell us who we are and where we come from. They also carry experiential and traditional knowledge from one generation to the next.

Oral history as a field of research, teaching, archival collection, community building or engagement, truth and reconciliation, and creative practice, emerged with the diffusion of the tape recorder in the 1960s and 1970s. This was a time of enormous social and political upheaval. As a result, oral history was quickly taken up by feminists, working-class and queer activists, racial minorities, and other marginalized people who sought to record the hidden stories that would otherwise be lost (Kerr, 2016; Baillargeon, 1993; Foisy \& High, 2015). Many people's stories never make it into "public" archives.

These radical origins have profoundly shaped the field. Ordinary people live extraordinary lives and these "little" histories are both shaped by, and shapers of, the "big" history that we usually hear about. Oral history teaches us that history inhabits each of us.

Yet, unlike ethnography, which is the disciplinary practice of anthropology, oral history has never found a secure home in our universities. It has had an uncomfortable relationship with the history discipline. There are a number of reasons for this. Historians study the past, not the present. We (as I am a historian too) actively suppress the present by writing in the third person and the past tense. In these ways, we historians distance ourselves from our objects of study. With distance comes clarity-at least this is the disciplinary logic (High, 2018).

Oral history has a very different modus operandi. Oral history is fundamentally about the relationship between the past and the present, placing memory front and centre. At their best, interviews place 
experiential authority (the "I was there, and I am going to tell you how it really was" kind of authority) into conversation with expert authority (people who bring some questions, maybe some training and distance). This approach to learning across difference and in dialogue represents a not-so-subtle shift from learning about to learning with. These differences in orientation are such that, until recently, there were few oral history courses offered in university history departments. Even today, there is only one graduate program in Oral History in North America (at Columbia University in NYC). Most oral historians, including myself, are therefore self-taught.

The good news is that the marginality of oral history in the academy has meant that it has emerged as a diverse community of practice. Oral historians can be found across the university. What's more, most people who self-identify as oral historians are found off-campus-in the communities that they serve. They are teachers, artists, archivists, social activists, and community members. This diversity means that oral history is much more than a research methodology. It has become a space of creative exchange and experimentation: a place of mutual encounter. ${ }^{1}$ We see this not only in the oral history interview, but also in what comes after it. Let me explain.

\section{The Oral History Interview}

Much like teaching, there is no one way to approach oral history interviewing. I have come to think of the interviewing as a mixed method.

1. Life story interview: The most common approach is the life story interview, where the conversation unfolds roughly chronologically. I often start with a question that asks people to tell me how far back do the stories in their family go? Then we talk about grandparents, parents, childhood, schooling, coming of age, young adulthood, work, and so on. This is even true if I am primarily interested in only a specific chapter in their lives. For example, to understand what forced migration means for refugees coming to Montreal, we need to know the "before" and the "after." Only then do we come to fully appreciate what it all means to them. The life story interview is adept at placing history within the context of a life lived and remembered. This is different than simply asking people to be an eyewitness to history. For example, to understand the impact of residential schools on indigenous people in Canada, we need to not only know what happened in those schools, but also how this violence rippled outward through individual lives and that of families and the wider community. It is a history that is very much present today, not something located in the distant past.

Of course, a life story interview is never as linear as this, as there is considerable time travel in any interview. The approach is flexible and most of the questions asked are follow-ups. It is important to avoid robotic questioning, and follow-ups show interview partners that we are listening. They also allow us to delve deeper. It is also important to give interviewees the space to share what they think is important. This may be the same life space that you are primarily interested in or something new. A good interview, notes Henry Greenspan (2006), is a working space where two people work really hard to understand the life of one person. Interviewees also often have questions themselves and they sometimes struggle to make sense of their own experiences. The key then is to spend time with people. It takes time to build rapport and trust. 
Some stories surface slowly. Life story interviews are usually 90 minutes to two hours, but can be as long as 20 hours of recorded interviews.

One of the issues that my students struggle with is when to know when an interview is "over." I often advise them to ask a large question or two at the end-something like, "Is there anything that we have not covered yet?" This often opens up another chapter of the interview. It also ensures that the interviewee doesn't leave the interviewee thinking that he or she really wanted to share a particular story, but never had the chance. ${ }^{2}$

2. Group interview: The stories that emerge in group interviews are not the same ones that emerge in individual ones. A life story interview is naturally centred on the individual's life course. A group interview is focused, instead, on the stories shared by those being interviewed. Interviewing couples together, and interviewing them separately, results in very different stories emerging. Group interviews are usually best when the group knows each other already, so the research is merely plugging into an existing conversation. I have conducted a number of group interviews over the years, mainly with couples. The most extreme example was in the 1990s when I was invited by a retirees' group of steelworkers in Buffalo, New York, to travel down and do a group interview. I had expected a group of 10 or 12, which was intimidating enough. When I entered the room, there were more than 100 people awaiting. I toured from table to table, the best that I could - recording some very important stories. One, in particular, still stands out in my mind. A steelworker told me that he heard about the closing of his steel mill on the radio. A few days later he got a call from his boss, who told him that he was eligible for a 35year service pin and asked if he still wanted it. The man said sure, and was told to come to the front gate the next day. When he did, his supervisor came out and passed it to him through the chain-linked fence as the gate was padlocked. A stunning story that reveals much about the sense of betrayal that permeates the US Rust Belt to this very day (Smith, 2015).

3. Photo interview: Another way to share memories is through photo elicitation. Flipping through a family photo album or a pile of old photos elicits new stories. Each photo has a story and the arrangement of photos in an album offers us much to think about. A photo interview does not have to be a stand-alone interview, but could be turned to at the end of a life story interview. A video or still camera is helpful here as an audio recording is ill-suited to capture these photocentred conversations. This can be done in individual or group interview contexts (Payne, 2011).

4. Memory mapping: Another interview form is the memory mapping exercise or workshop where a person is asked to draw on a blank piece of paper. It could, for example, be their childhood world or home place. Or a workplace, school, or other physical site of memory. Real maps can also be introduced, where people are asked to locate memories and draw boundaries. Here, too, very different memories or stories emerge. A mapping exercise can also be integrated into a life story interview, especially with respect to the very localized memories of childhoods.

5. Walking interview: If your core interest is place, and that place is nearby, why wouldn't you go there with your interview partners? The walking interview has emerged as a popular way to elicit place memories. In these interviews, the built and natural environment becomes a prompt for remembering-intervening into the conversation, making it three-way. It is important to let interviewees determine the route, as this too, tells us something. You can imagine a series of walking interviewees in a single neighbourhood, each taking its own trajectory. 
These memories are anchored in what you can see, hear, smell, or touch. Here past and present collide, as people point to what was once there, and what is there now. Urban change is often at the heart of these conversations. They are mobile, but walking interviews are much more localized than a sit-down interview at a kitchen table where the interviewer is free to span continents as well as decades in his or her recounting.

Oral historians are increasingly combining oral history interviewing with other cross-disciplinary methodologies such as Photovoice (where you ask your interview partners to take their own photos and then share stories), digital storytelling (where people are asked to narrate and compose their own stories and go public with them), and arts-based or participatory media methodologies. ${ }^{3}$ The possibilities are endless. I prefer to think of oral history as a creative practice, open to adaptation and experimentation.

Most oral history projects focus on those we like or empathize with. However, it is also important to listen across political differences. This even extends to those we abhor. Historian Kathleen Blee (1993), for example, interviewed women involved in the Ku Klux Klan to understand why people hate. It is easy to dismiss these people, but it is more important to understand. I had a graduate student, Erin Jessee (2017), who likewise interviewed a convicted genocidaire in the Rwandan prison system. She wanted to know why people kill? These are never easy places to go, but they are necessary ones.

Luckily, most oral history interviewing is not nearly as difficult. My undergraduate students often interview a grandparent or another elder in their life. I therefore teach them some of the fundamentals of oral history interviewing - to take your time, ask straightforward open-ended questions, to respect silence and not to fill it too quickly. And it is important to plan your day so that you are not concerned about time during the interview. Students should plan for a three-to-four hour stay. There is always transitional time before and after the interview. It is also important to give back to interviewees, giving them a copy of the interview and ideally the research-creation project produced from it. It is essential that we are accountable to the communities that we work with. For more, check out the webinars available on the website of the Centre for Oral History and Digital Storytelling. ${ }^{4}$

\section{Ethics in Oral History}

University students and faculty in Canada are subject to mandatory ethics reviews. This is a good thing, as there has been considerable abuse in the past. There are also ethics requirements in other educational contexts. A consent form is a minimum-allowing interviewees to determine how their interview is to be used. Ethics is a lot about diffusion. Is the person to be named or not? Will the interview be archived and available to others? Will it be available online? And so on. At Concordia, we think of the consent form as a right of use agreement, rather than a copyright transfer agreement. We feel this distinction is important as we often work with marginalized communities. These are their stories. In my workshops, I often cite a British example where a project on HIV used copyright transfer agreements. The interviews were transcribed and then donated to the British Library. However, when one interviewee wanted to use the transcript as the first draft of his autobiography, he had to write for permission from the British Library. 
This is just wrong. But for a right of use agreement to mean anything different, the interviewee must be told about the intended uses. ${ }^{5}$

Another tricky issue is confidentiality. If an interviewee does not wish to be named, how can we guarantee this person anonymity to others. There have been a number of legal cases in the United States and Canada which have revealed the inability of oral historians and other qualitative researchers to protect the identity of their confidential sources. We are not like medical professionals or religious people: there is no cone of silence around our work. The law therefore trumps our ethics. This happened at Boston College where an interview project with IRA bombers led to a subpoena from a Northern Irish court for access to interviews that were supposed to be closed for 20 years. Here, in Canada, the Magnotta trial revealed similar issues when confidential interviews were reviewed as part of a murder trial. Our practice at Concordia is to transcribe confidential interviews, return the transcription to interviewees for approval (where they can make any additional changes they wish), and then produce a public transcript. The original interview recording is then destroyed. This is the only way to cut the link. ${ }^{6}$

Other issues include mitigating harm, the right of withdrawal, and so on. I could speak to each of these. Many of these ethical issues are best resolved through collaboration. The more that researchers work with community members, the more secure the process becomes (see Miller, Little, \& High, 2017). This is particularly urgent when working with marginalized people. Being aware of one's own privilege and positionality is crucial to this.

\section{Teaching Oral History}

Students in my oral history classroom learn by doing. They have to envision their projects, go through ethics review, interview, transcribe, interpret, and go public with their work. I encourage students to go public in creative ways. Students have produced graphic stories (Rebecca's Oral History Odyssey https://oralhistoryodyssey.wixsite.com/oralhistoryodyssey), audio walks (www.postindustrialmontreal.ca

— go to La Pointe Audio walk produced by my class), online digital stories, live performances, visual or sound art, composed music or poetry, and so on. They have also written blogs, newspaper articles, and research papers. 


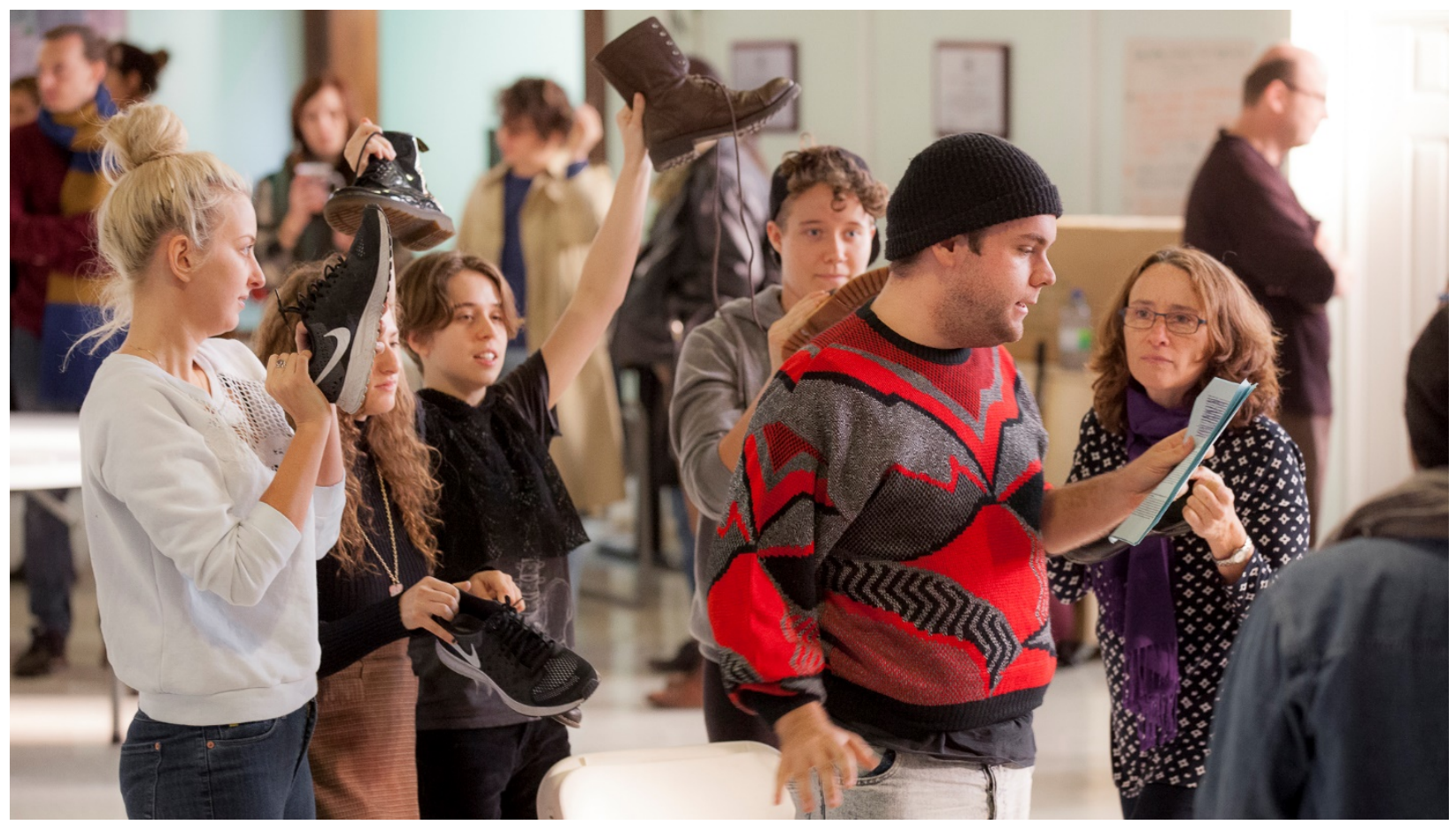

Fig. 1: Oral history students performing story with theatre students at Share the Warmth in Point Saint Charles. 2016. Photograph by David Ward.

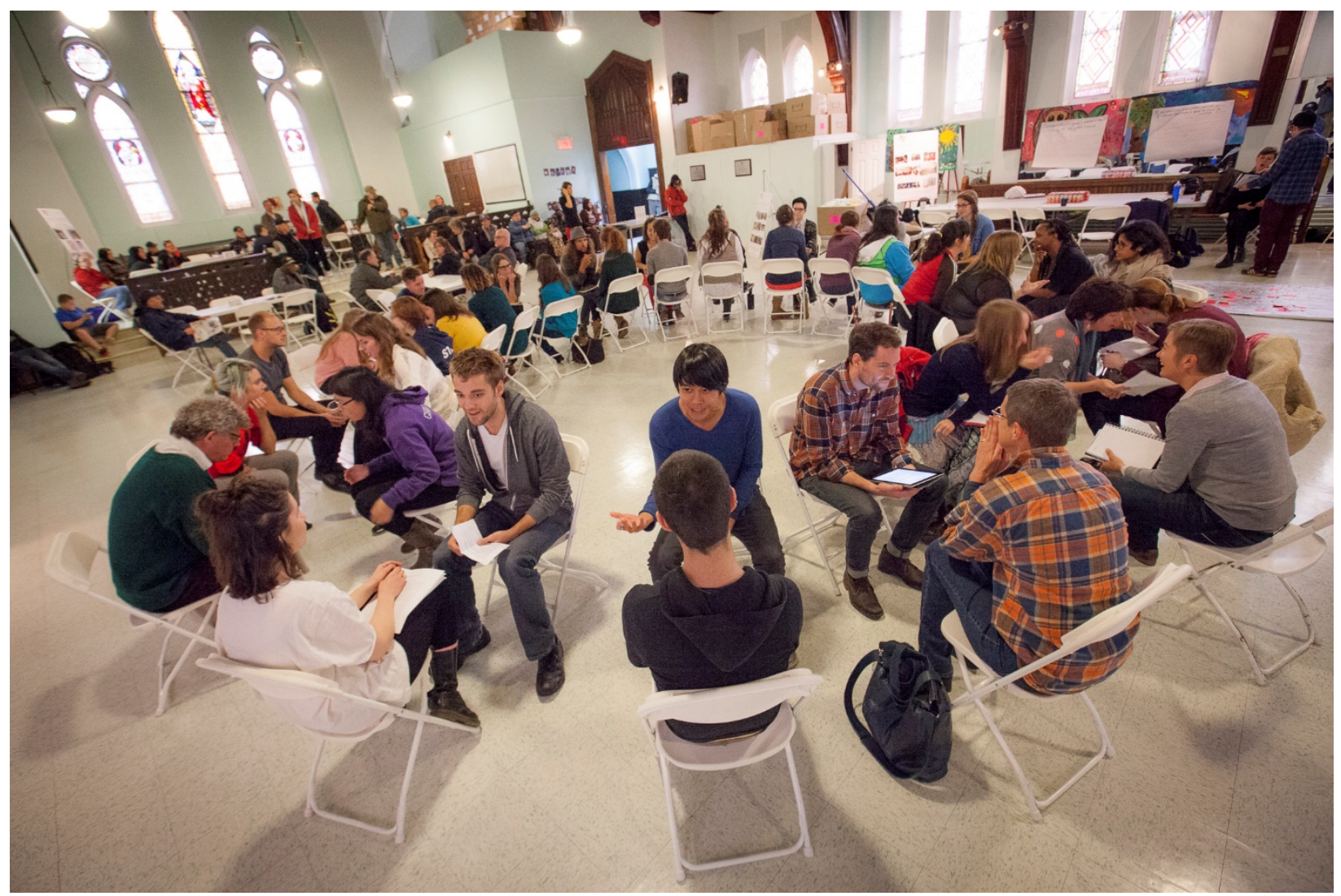

Fig. 2: The speed-dating-with-history exercise. Share the Warmth. Point Saint-Charles. 2016. Photograph by David Ward. 
I have played with the many ways that they can listen to story. One popular exercise is known as the "speed-dates-with-history" assignment. Here students are each assigned a recorded interview to watch/listen to at the Centre for Oral History and Digital Storytelling (storytelling.concordia.ca). They have to become an "expert" on that person's life, taking notes as they listen. They then have to perform that person's story in the first person. Imagine a class of 45 students organized in two concentric circles with the chairs facing each other. At the sound of a gong, students in the inner circle have 90 seconds to introduce themselves as their interviewee. Then, the students on the outer circle do the same. They all shift right (which means in opposite directions) and they have to do this again, and again. The exercise is designed to create "ethical squirm" as people are forced to pretend to be people unlike themselves. Race, gender, generation, class, and other markers of identity separate them. This exercise therefore teaches us much about the politics of representation. We represent people all the time through our writing without a second thought, but when we have to embody that person it all comes home. How people choose to represent voice, body language, and so forth are all food for thought. After the exercise we have a debriefing period where we talk about the learning-the decisions they made in representing their interviewee, what they found difficult, and how their interpretation evolved over the four to five iterations. Sometimes they encounter another student who is representing the same interviewee-and this raises an opportunity to think about the different approaches taken.

There is a growing interest in teaching oral history at all levels of education. I have identified some of the best published work out there. ${ }^{7}$ It is an exciting time to be working with personal story.

\section{Notes}

1. Alessandro Portelli is the leading light of global oral history. His notion of oral history as mutual encounter comes from his book, The Death of Luigi Trastulli and Other Stories: Form and Meaning in Oral History (Albany, NY: SUNY, 1991). The chapter on "What makes oral history different?" is particularly relevant to those getting started.

2. An excellent general guide is offered by Paul Thompson and Joanna Bornat (2017), The Voice of the Past. Fourth Edition (Oxford: Oxford University Press). There is a vast scholarship on oral history interviewing. Among my favourites are Anna Sheftel and Stacey Zembrzycki (2013), Oral History Off the Record: An Ethnography of Practice (New York, NY: Palgrave Macmillan); Henry Greenspan and Sidney Bolkosky (Summer 2006), "When is an Interview an Interview? Notes from Listening to Holocaust Survivors," Poetics Today 27, 2, 431-449; and, Julie Cruikshank (1998), The Social Life of Stories: Narrative and Knowledge in the Yukon Territory (Lincoln, NB: University of Nebraska Press).

3. There are many examples of creative outputs of oral history. For some Montreal examples, see Catherine Charlebois and Jean-François Leclerc (2015), "Les sources orales au coeur de l'exposition muséale. L'expérience du Centre d'histoire de Montréal," Revue d'histoire de I'Amérique française 69, 1-2, 99-136; Steven High (2015), Oral History at the Crossroads: Sharing Stories of Displacement and Survival (Vancouver: UBC Press); Edward Little and Steven High (2014). "Partners in Conversation: Ethics and the Emergent Practice of Oral History Performance," in David Dean, Yana Meerzon, Kathryn Prince (Eds.), History, Memory, Performance (New York, NY: Palgrave Macmillan), 240-256; and, Hourig Attarian and Rachael 
Van Fossen (2013), "Stories Scorched from the Desert Sun: Performing Testimony, Narrating Process" in Steven High, Edward Little and Thi Ry Duong (Eds.). (2013). Remembering Mass Violence: Oral History, New Media and Performance (Toronto, University of Toronto Press).

4. http://storytelling.concordia.ca/toolbox/training/webinars

5. For examples of consent forms and other ethics advice, see the website of the Centre for Oral History and Digital Storytelling: http://storytelling.concordia.ca/toolbox/ethics. COHDS offers free public workshops on a regular basis. If you are based in the Montreal area, you are most welcome to drop in.

6. Some of the more interesting ethics articles include: Valerie Yow (1995). "Ethics and Interpersonal Relationships in Oral History Research." Oral History Review 22, 1, 51-66; Robin Jarvis Brownlie and Roewen Crowe (2014), "So You Want to Hear Our Ghetto Stories? Oral History at Ndinawe Youth Resource Centre" in Steven High, Edward Little, and Thi Ry Duong (Eds.), Remembering Mass Violence: Oral History, New Media and Performance (Toronto: University of Toronto Press); Katherine Borland (1991), “'That's Not What I Said': Interpretive Conflict in Oral Narrative Research" in Sherna Berger Gluck and Daphne Patai (Eds.), Women's Words: The Feminist Practice of Oral History (New York, NY: Routledge).

7. For a general collection of educational projects, see: Kristina R. Llewellyn and Nicholas Ng-AFook (Eds.). (2017), Oral History and Education: Theories, Dilemmas, and Practices (New York: Palgrave Studies in Oral History), especially Julie Perrone's chapter on inspiring Canadian elementary and secondary teachers who use oral history. The next article is coauthored by a secondary school teacher and student about a term-long project. The article was written while Noelia was still in high school, went through peer review when she was at CEGEP, and finally appeared in print when she was at university. Noelia Gravotta and Megan Webster (2013), "CoCreating Our Story: Making a Documentary Film" in Steven High, Edward Little and Thi Ry Duong (Eds.), Remembering Mass Violence: Oral History, New Media and Performance (Toronto: University of Toronto Press). Other oral history in Montreal classrooms include: Bronwen E. Low and Emmanuelle Sonntag (2013), "Towards a Pedagogy of Listening: Teaching and Learning From Life Stories of Human Rights Violations," Journal of Curriculum Studies; Michele Luchs and Elizabeth Miller (2015), "On Tour With Mapping Memories: Sharing Refugee Youth Stories in Montreal Classrooms," in Steven High (Ed.), Beyond Testimony and Trauma: Oral History in the Aftermath of Mass Violence (Vancouver: UBC Press), 235-256; Stacey Zembrzycki and Steven High (2012), "When I was your age': Bearing Witness in Holocaust Education in Montreal," Canadian Historical Review, 93, 3, 408-435. I reflect on my own teaching practice in Oral History at the Crossroads: Sharing Life Stories of Survival and Displacement. (Vancouver: University of British Columbia Press, 2014) and in the sixth chapter of Going Public. 


\section{References}

Baillargeon, D. (1993). Histoire orale et histoire des femmes: Itinéraries et points de rencontre. Recherches Féministes, 6(1), 53-68.

Blee, K. (1993). Evidence, empathy and ethics: Lessons from oral histories with the Klan. Journal of American History, 80, 2, 441-469.

Foisy, C., \& High, S. (2015). Un chantier à réinvestir ou à réinventer: Histoire contemporaine du Québec et sources orales. Revue d'histoire de l'Amérique française, 69, 1-2, 1-18.

Greenspan, H., \& Bolkosky, S. (Summer 2006). When is an interview an interview? Notes from listening to Holocaust survivors," Poetics Today, 27, 2, 431-449.

High, S. (2018). Storytelling, Bertolt Brecht, and the illusions of disciplinary history. In David Dean (Ed.), A companion to public history. New York, NY: Wiley-Blackwell.

Jessee, E. (2017). Negotiating genocide in Rwanda: The politics of history. New York, NY: Palgrave MacMillan's Studies in Oral History series.

Kerr, D. (2016). Allan Nevins is not my grandfather: The roots of radical oral history practice in the United States. Oral History Review, 43(2), 367-391.

Miller, E., Little, E., \& High, S. (2017). Going public: The art of participatory practice. Vancouver: University of British Columbia Press.

Payne, C. (2011). 'You hear it in their voice': Photographs and cultural consolidation among Inuit youths and elders. In Alexander Freund and Alistair Thomson (Eds.), Oral history and photography. New York, NY: Palgrave-Macmillan.

Smith, G. (2015). Remembering in groups: Negotiating between 'individual' and 'collective' memories. In Robert Perks and Alistair Thomson (Eds.), The oral history reader (3rd ed.). London: Routledge.

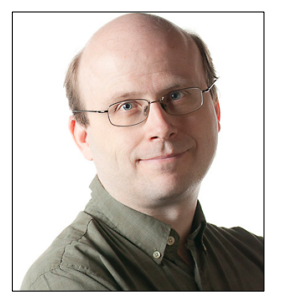

Steven High is a Professor of History at Concordia University where he cofounded the Centre for Oral History and Digital Storytelling. His research has received numerous awards including the Clio Prize for the best book published on Quebec History, the Klibansky Prize for the best book published in the humanities in Canada, the Albert Corey Prize from the American Historical Association for the best book published in Canada-US relations, and the Porter Prize in Canadian sociology. 
48 | LEARNing Landscapes | Spring 2018, Vol. 11 No. 2 